\title{
Problems and Countermeasures ofUniversity-affiliated Scientific and Technological Enterprises under the Background of New Normal
}

\author{
Yunshan Liu ${ }^{1}$ \\ ${ }^{1}$ School of Education, Wuxi Institute of Commerce, Wuxi,Jiangsu Province, China
}

Key words: scientific and technological enterprises; university-affiliated; colleges and universities; problems; countermeasures

\begin{abstract}
Since thereform and opening up, many universities and colleges have established high-tech enterprises. Although achieve great development, these university-affiliated technology enterprisesare still faced with operational problems on concept, management system, operation mechanism and other aspects. With the development of Chinese economy, the state increases supports on high-tech enterprises.University-affiliated technology enterprises should follow the trend and seize the opportunity, trying to realize these problems and put forward to reform strategy, so as to realize the sustainable development.
\end{abstract}

\section{Introduction}

Since the reform and development, a large number of university-affiliatedscience and technology enterprises, such as Tsinghua Tongfang and Peking University Founder, have been established. These companies have made brilliant achievements. But with the changing economic situation, they are now faced with fierce market competition.These companies are gradually losing their competitive advantages, and coming to the edge of being eliminated.Various contradictions and difficulties emerge in their operation process. Therefore, in the trend of new normaland supply-side structural reform, university-affiliated high-tech enterprises should be fully aware of problems in their operation systems. On that basis, they need to adhere to the concept of sustainable development, optimize their operation modesand keep pace with the times, in order to constantly enhance the competitiveness and influence of enterprises.

\section{Existing Problems of University-affiliated Scientific and Technological Enterprises}

Little attention and misunderstandings. At present, the authorities of some colleges and universities do not pay enough attention to the development of university-affiliated high-tech enterprises.School leadersdo not attach importance to the running of high tech enterprises.Most leaders and teachers still pay more attention to theory study rather than application.They do not realize the importance of commercialization of research findings, and believe that the main tasksof universitiesare teaching students, as well as research scientific and technological achievements. Science and technology industry are in high risk, and they are lack of related experience. So they prefer to direct transfer their scientific and technological achievements.Some leaders and teachers think that the development of science and technology enterprises will distract teachers' attention from education, and will affect the overall teaching level and the stability of teachers. Some leaders, teachers and students believe that these technology enterprises are established to solve theproblem of school funding shortage, and do not fully recognize that scientific and technological enterprises consist an important part of the work of colleges and universities. They set their goal of running enterprises as making money, and refuse topay back to their colleges and universities timely. [1]

Unclear property relations and the mix of university and enterprise. These enterprises are invested directly byuniversities and colleges, and are operated by school teachers who are lack of experience and knowledge on modern enterprise management.Thus, the operation of enterprisesmay not go well with market economy, and there's no clear boundary between the school and the enterprise. This is mainly because, high-tech enterprises have different property and operation mode 
from schools; but in actual operation process, schools and enterprises often mix with each other.Although from the legal perspective, the property rights of enterprises belongto schools, the improper arrangement of property rights will lead to unclear business nature and property rights, as well as themismatch of interests and rights. Many colleges and universitiesrefer to their experiences on laboratory management, and adopt the approach of administrative management in enterprises. School authorities meddle inevery aspect of enterprise management, especially in personnel arrangement and investment decision. Some colleges and universities even combinethe financial department of enterprises with the financial sectors of schools. Under that situation, enterprises cannot realize independent decision-making and management; their vitality is dampened by redundant management system. In addition, enterprises pursue for economic benefits, while campus pursue for social benefit. The different enterprise and school cultures can influence each other, and make high tech enterprises cannot adapt to the needs of market economy. The development of enterprises is hindered.

The advantages of science, technology and intelligence arenot given full play; the transfer ratio of research achievements is low. Scientific and technological enterprises affiliated tocolleges and universities should make full use of their advantages on scientific research, talents and intelligence. High-quality teachers and scientific research teams are their unique merits. At the same time, universities and colleges are rich in research experience and equipment, which helps enterprises to get advantages on scientific research and innovation sources. Relying on advantages of scientific research and the market economy, universities and colleges can apply more scientific research results to practice, and improve the scientific and technological influences of China.But university enterprises do not have mature mechanism or awareness ontechnological achievements transformation. The lack of funding also restricts universities to cooperate with social enterprise. The serious gap between social enterprises and universities causes a lot of problems. On one hand, a large number of scientific achievements in colleges and universities cannot be transformed into social productive forces.On the other hand, enterprises cannot get enough supportsfrom scientific research. Relevant data show that, in China, the transfer ratio of scientific and technological achievements in universities is less than 10\%; the overall transfer ratio of scientific and technological achievements is less than $30 \%$.

Unclear restriction and incentive mechanisms. From a long-term perspective, the development of an enterprise needs constraint mechanism and incentive mechanism.Therefore, science and technology enterprises must establish a scientific incentive mechanism on the basis of distribution according to work, fully reflect the value of labors, better payment for better work, and survival of the fittest. But at present, due to the unclear relationship between ownership rights and responsibilities, enterprises cannot be separated with schools. Under the influence oflong-term egalitarianism and planned economy, enterprises do not have strict requirements on staffs, and the incentive mechanism is not perfect.Staffsdo not have the sense of responsibility and dedication. From the perspective of organization arrangement, the most prominent problem is the lack of entrepreneur cultivation mechanism. The fierce competition requires professional management personnel in enterprises. But in the past, most of the management personnel were directly appointed by the university. These managers were also school leaders. Thus, they did not seek for occupation promotion, and were lack of management experience, which lead to the poor efficiency of enterprises.

Shortage of funds and the lack of venture capital mechanism. At present, most capitals of university affiliated scientific and technological enterprises come from educational funds invested by the state. According to relevant laws and regulations, the state earmarks funds for specified purposes only. Judging from the structure of appropriation, funds allocated by the state do not includeauthorized special funds on developing scientific and technological enterprises. Therefore, in order to avoid the outflow of funds, many colleges and universities invest capitals in affiliated science and technology enterprises, and then withdraw the funds after registration. In this way, enterprises become shell firms which cannot develop consciously. Apart from a small number of large enterprises, low investment is the short board that 
restricts the innovation and development of enterprises. The main task of colleges and universities is education, and their fundsources are limited. What's more, the rapid development of higher education gives rise to phenomena offund shortage. Except for famous universities like Peking University, Tsinghua University and Zhejiang University, science and technology enterprises of most colleges and universities are in small scale, and are facing the problem of serious funds shortage. They cannot get investment from venture capital, so it is difficult for them to expand production scale, achieve the commercialization and industrialization of scientific and technological achievements, and take part in market competition.

\section{Countermeasures to Problems Existed in University-affiliated Scientific and Technological Enterprises}

Strengthen school authorities' attention on scientific and technological enterprises. Although there are still a lot of problems in the development of university affiliated scientific and technological enterprises, the importance of enterprises should be fully recognized during the process of enterprise management. First of all, universities and colleges have academic atmosphere, while the society has obvious economic characteristics. There is a gap between universities and the society, which will lead to the same problem in students' education.University affiliated enterprises can solve this problem by setting up the bridge between the university and society. Secondly, in enterprise management process, some teachers are access to more knowledge on industries, which will help them to expand horizons, and cultivatediversified students. Finally, enterprises can apply more scientific research achievements to the society and create social benefits.

Combination involving production, teaching and research; enhancing the competitiveness of enterprises. The competition in Chinese market is always fierce. If an enterprise wants to survive and develop, it must adapt to the competitive environment. Only companies with advantages in technology, talentsand resources can win in the competition. Therefore, ifuniversity affiliated enterprises want to achieve long-term development, universities should increase their investment in scientific research and talents cultivation. The combination of industry, university and research can train innovative talents, and make great contributions to the development of Chinese economy. The strategy ofindustry, university and research combination can be implemented from perspectives of consultation and planning, commercialization of scientific and technological achievements, matchingnational development strategy, international exchanges and cooperation, as well as personnel training and education.Principles of innovation, complementary advantages, mutual support and common development should be adhered to establish collaborative innovation mechanism, and further strengthen the competitiveness ofscience and technology enterprises affiliate to colleges and universities. In the business process, enterprises must pay attention to the market. They shouldcarry out relevant researches on market demands, and make plans on enterprise development and product innovation according to research results, in order to constantly enhance the overall influence of enterprise products, promote competitive products, determine the development direction,and realize the commercialization of scientific and technological achievements.

The most important thing for enterprises is to improve their technological innovation capabilities.Technology innovation has a direct impact on the vitality of products and the long-term development of enterprises.In order to accelerate the innovation of science and technology, innovations on system, management, market, product and knowledge should also be enhanced and improved constantly. Therefore, enterprises must keep pace with the world, the society and the industry, improve the transfer ratio of scientific and technological achievements, continue to introduce new technologies, products and technology, and constantly improve the technological innovation capability. After obtaining scientific and technological achievements, colleges and universities should actively carry out industry-university-research cooperation, and transform scientific and technological achievements. In the development process, university-affiliatedscience and technology enterprises need to recognize their own strengths and weaknesses, share risks through cooperation with social enterprises, form a perfect research system, improve economic 
benefits and the transfer ratio of scientific and technological achievements. In this process, part of enterprise earnings should be paid back to support scientific research in universities and colleges. The corresponding incentive system should be established to arouse the enthusiasm of talents,improve their capabilities of independent innovation, and create new economic growth points.

Cultivating innovative consciousness on enterprise management and adopting modern enterprise management system. Under the unfavorable world economic conditions, in order to promote the development of enterprises, enterprise managers need to establish the consciousness of innovation, accelerate the pace of management innovation, promote innovative activities, trying to achieve comprehensive reformand overall improvement, as well as the continuously improvement of innovation performance. First, they can introduce advanced methods and tools from foreigncountries, and upgrade the overall management system. Second, through independent research and development, these enterprises can master the core technique; through differentiation strategy and market segment, they can find new business models.Third,equal attention should be paid to scientificresearch and management, in order to promote independent innovationsand enhance innovation abilities. Fourth, enterprise managers should raise the level of informatization on enterprise management, so as to minimize the influences of personal behaviors on organization operation, and improve management efficiency. Fifth, they ought to pay attention to brand, reputation and corporate image, as well as the accumulation of knowledge assets. Humanistic management should be adopted.Enterprise managers can emphasize the values of the enterprise to employees, advocate innovation and pursue for harmony. At the same time, a modern enterprise system should be established to improve the incentive and restraint mechanismsofuniversity affiliated scientific and technological enterprises.[2]Scientific and technological enterprises affiliated tocolleges and universities should carry out restructuring in strict accordance with the requirements of Company Law, and establish a modern enterprise system with clear regulations on property rights, interests and responsibilities, as well as the boundary between school and enterprise. Only in this way, can scientific and technological enterprises affiliated tocolleges and universities achieve further development. At the same time, the corporate governance structure of western countries can be adopted. First,they can establish enterprise corporation property system and limited liabilitymechanism to reduce shareholders' financial risks.Second,the investment system of university affiliated science and technology enterprises should be improvedto absorb social investment. Third, through the construction of new equity system, the supervision mechanism could be strengthened. These science and technology enterprises should make clearly regulations on equity and property rights, strengthen enterprise management and supervision, and establish the internal ESOP mechanism.Employees who hold shares will help to supervise corporationoperation and financial affairs. This new type of ownership structure is conducive to the modernization of enterprise management. ESOP can significantly improve staffs' enthusiasm and sense of responsibility, which will help university-affiliated science and technology enterprises to enter the market. This ownership structure guarantees owners' rights and interests, gives full play to the management autonomy of managers, and promotes the long-term development of enterprises.

Striving for getting venture capitals,and accelerating the pace of development through capital operation. In recent years, financing problems plague enterprises. Though the government has introduced corresponding support policies, it cannot solve the problem permanently.In order to develop, many enterprises turn to seek the help of venture capitals. Large amount of funds are needed by scientific and technological enterprises affiliated tocolleges and universities, but their sources of funds are limited.In addition, these enterprises are often in small scale, which lead to difficulties ingetting loans from financial institutions. For high-tech enterprises, the special function of venture capital market is that, it can stimulate innovation and foster the high-tech industry through the unconventional allocation of resources. Venture capital market can cultivate high-tech enterprises;it provides enterprises at all stages of growth and development with corresponding capital sources. University-affiliated technology enterprise is an integral part of the high-tech industry; they have features like high risk in technological innovation andgreat demands on 
intellectual capitals;common financial institutions are reluctant to get involved in these enterprises, though they are potentially lucrative [3]. The shortage of funds in colleges and universities restricts the development of enterprises. What's more, the long development cycle and great risk of projects bring difficulties in financing fromnormal channels. At present, with the continuous development of higher education in China, colleges and universities possess advantages in talents, knowledge and technology.Currently,the economic transformation in China is in key period.Some projects on environment protection, intellectualization and advanced manufacturing technology are the focus of development.A considerable part of industrial capital is looking for new investment hot spots, which provides these enterprises with the feasibility of co-operation. In the past, due to historical reasons on economic system, many enterprises were invested directly by colleges and universities. But in the future, we needa more diversified capital investmentmechanism which can take advantage of talents and knowledgeresources in colleges and universities.

\section{References}

[1] X. Shao, Problems and countermeasures on the commercialization of research findings of universities and colleges, J. Science and Technology Progress. 2 (2013)

[2] L. Li, Problems and countermeasures in Chinese evaluation system of scientific and technological achievements, J. Science and Technology Information. 26 (2012)

[3]S.M. Wei, S.Y. Li, Study onpromoting the commercialization of research findingsin local universities and colleges, J. Innovation and Technology. 6 (2015). 